\title{
Sixty-One Years Following Registration, Phorate Applied In-Furrow at Planting Suppresses Development of Late Leaf Spot on Peanut
}

\author{
Daniel J. Anco, ${ }^{1, \dagger}$ James S. Thomas, ${ }^{1}$ David L. Wright, ${ }^{2}$ Nicholas S. Dufault, ${ }^{3}$ and Ian M. Small ${ }^{2,}$ \\ ${ }^{1}$ Department of Plant and Environmental Sciences, Clemson University, Edisto Research and Education Center, Blackville, SC \\ 29817 \\ ${ }^{2}$ North Florida Research and Education Center, University of Florida, Quincy, FL 32351 \\ ${ }^{3}$ Department of Plant Pathology, University of Florida, Gainesville, FL 32611
}

\begin{abstract}
Late and early leaf spot are caused by Nothopassalora personata and Passalora arachidicola, respectively, and are damaging diseases of peanut (Arachis hypogaea L.) capable of defoliation and yield loss. Management of these diseases is most effective through the integration of tactics that reduce starting inoculum and prevent infection. The insecticide phorate was first registered in 1959 and has been used in peanut production for decades in-furrow at planting to suppress thrips. Phorate further provides significant suppression of Tomato spotted wilt virus infection beyond suppression of its thrips vector alone by activating defense-related responses in the peanut plant. From six experiments conducted from 2017 to 2019 in Blackville, SC, Reddick, FL, and Quincy, FL, significantly less leaf spot defoliation was exhibited on peanuts treated with phorate in-furrow at planting (26\%) compared

experiments, significant suppression of defoliation caused by late leaf spot was observed from 64 to 147 days after planting. Although more variable within location-years, pod yield following phorate treatment was overall significantly greater than for nontreated peanut $(2,330$ compared with $2,030 \mathrm{~kg} / \mathrm{ha} ; P=0.0794)$. The consistent defoliation suppression potential was estimated to confer an average potential net economic yield savings of $\$ 90$ to $\$ 120$ per hectare under analogous leaf spot defoliation. To our knowledge, these are the first data in the 61 years since its registration demonstrating significant suppression of leaf spot on peanut following application of phorate in-furrow at planting. Results support phorate use in peanut as an effective and economical tactic to incorporate to manage late and early leaf spot infections and development of fungicide resistance.
\end{abstract} with nontreated checks $(48 \%)$. In-season fungicides were excluded from five of the experiments, whereas the 2018 Quincy, FL, experiment included eight applications on a 15-day interval. Across individual
Keywords: Arachis hypogaea, Nothopassalora personata, Cercosporidium personatum, groundnut, Thimet
From 2013 to 2017, annual production of peanut (Arachis hypogaea L.) in the United States has averaged 615,000 ha and represented a production value in excess of $\$ 1.22$ billion (https://www.nass.usda. gov/). Late leaf spot is caused by Nothopassalora personata (Berk. \& M.A. Curtis) S.A. Khan \& M. Kamal (syn. Cercosporidium personatum [Berk. \& M.A. Curtis] Deighton) and can produce yield losses upward of $70 \%(\$ 1,390 / \mathrm{ha}$, assuming disease-free yield potential) without effective fungicide applications (Anco et al. 2020c). Not including yield losses due to disease, fungicide management costs alone can exceed \$250/ha. Recommended management of late leaf spot conforms to the integration of multiple strategies to reduce disease development (Anco et al. 2019; Kemerait et al. 2018).

In practice, limitations to conceivable simultaneous combined utilizations of all possible integrated pest management (IPM) tools in commercial production stem from varying sources. Constraints can include limitations to seed availability of individual resistant cultivars with commercially superior agronomic, processing, and marketing characteristics, cultivar specifications per available

${ }^{\dagger}$ Corresponding authors: D. J. Anco; danco@clemson.edu and I. M. Small; ismall@ufl.edu

Funding: Support was provided by the South Carolina Peanut Board. This material is based upon work supported by the NIFA/USDA, under project number SC-1700532.

Technical Contribution No. 6823 of the Clemson University Experiment Station.

The author(s) declare no conflict of interest.

Accepted for publication 6 May 2020.

(C) 2020 The American Phytopathological Society contracts (e.g., parts of the Virginia-Carolina region are moving to produce only high-oleic peanuts and do not offer contracts for normal-oleic cultivars including 'Georgia-12Y' [Branch 2013], which has resistance to leaf spot), and loss of fungicide efficacy. Fungicides are applied on approximately $92 \%$ of all peanut hectares grown in the United States, and a production value increase of $\$ 389$ million has been attributed to their use (Gianessi and Reigner 2005). Development of fungicide resistance has affected several compounds and fungicide groups, including the quinone outside inhibitors and systemic demethylation inhibitors (Culbreath et al. 2016, 2018; Munir et al. 2020), contributing to reduced control, increased buildup of inoculum, and greater costs of management. Recent studies have also indicated that levels of leaf spot resistance to some of the succinate dehydrogenase inhibitors are being observed in commercial peanut fields (Munir et al. 2020). Most fungicides labeled in peanut have single-site activity, with several being mixes of single-site active ingredients. Across a variety of cropping systems, cases of fungicide resistance to single-site active ingredients have been documented to develop in as little as 2 to 5 years following product introduction (Deising et al. 2008; Hewitt 1998). Furthermore, since 2016 revised maximum residue level restrictions in the European Union (EU) have limited use of specific active ingredients (e.g., propiconazole) on peanuts in the United States for the international export market and may restrict additional fungicides in the future (World Trade Organization 2016). In addition, the European Standing Committee on Plants, Animals, Food and Feed voted in March 2019 to ban the multisite fungicide chlorothalonil in the EU. Chlorothalonil is annually used on an estimated 72 to $93 \%$ of all U.S. peanut hectares (U.S. EPA 1999). Although it is as yet unclear whether or not the EU's decision will impact peanut production practices in the United States, it is clear that new management methods are required in order to both address current leaf spot management challenges and increase resiliency of peanut production into the future. 
Similarly, just as fungicide options can over time become less effective due to resistance or less available due to legislative restrictions, certain resistant peanut cultivars have become more susceptible over time. When first released, several Virginia-type cultivars such as 'Bailey' and 'Sullivan' exhibited effective partial resistance to leaf spot infections, and Bailey has since become the most widely grown cultivar in the Virginia-Carolina region (Isleib et al. 2011, 2015; Mehl 2017). Use of such resistant cultivars, including resistant runner-type peanuts (the predominant peanut market type in the southeast United States) such as Georgia-12Y or 'TifNV-High O/L' (Holbrook et al. 2017), decreases the overall risk of damaging leaf spot development and contributes flexibility in choice of fungicide programs contributing to effective management (Kemerait et al. 2018). However, in recent years since 2016 these listed Virginia-type varieties have exhibited substantially increased susceptibility to economically severe levels of leaf spot infection in research field trials and commercial grower fields alike (Anco et al. 2019).

As with most other diseases, management of leaf spot is more effective when tactics are implemented to prevent the disease from developing, rather than attempting to limit its development once infections become established. Along these lines, fungicide programs that begin earlier in the growing season are generally more capable of preventing severe disease development. Application of fungicides infurrow at planting is the earliest a fungicide can be applied to provide protection for growing tissues. Currently available options for infurrow application with peanut for leaf spot include the fluopyram component of imidacloprid plus fluopyram (Velum Total, $\sim \$ 84 / \mathrm{ha}$, Fungicide Resistance Action Committee [FRAC] mode of action code 7), fluopyram plus prothioconazole (Propulse, $\sim \$ 82 / \mathrm{ha}$ ), and prothioconazole (Proline, $\sim \$ 57 /$ ha, FRAC 3) (FRAC 2019). Of these options, only imidacloprid plus fluopyram provides protection
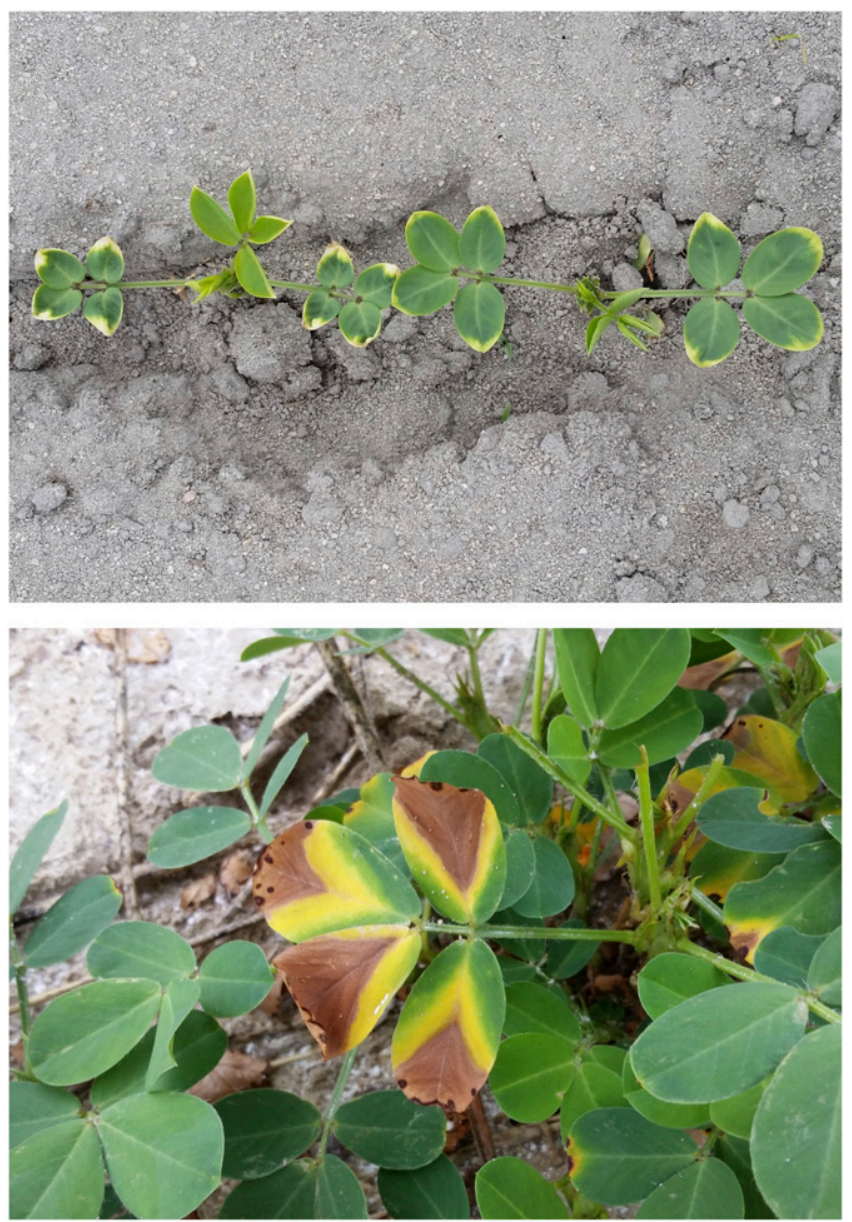

Fig. 1. Foliar phytotoxicity on peanut following in-furrow application of phorate at planting. against thrips, vector of Tomato spotted wilt virus (family Tospoviridae, genus Orthotospovirus); however, imidacloprid also increases the amount of spotted wilt development (Anco et al. 2020b; Culbreath and Srinivasan 2011; Marasigan et al. 2016). This phenomenon has been attributed to imidacloprid affecting thrips feeding behavior, increasing the number of inoculations (Chaisuekul and Riley 2001; Culbreath and Srinivasan 2011; Riley 2007). Use of prothioconazole at planting would still require an in-furrow insecticide to manage thrips and corresponding tomato spotted wilt (TSW) in most situations, adding to overall production costs. Although imidacloprid plus fluopyram also has activity against nematodes (Faske and Hurd 2015; Jackson et al. 2014; Oka and Saroya 2019), its cost can be less economical for fields where nematodes are below economic thresholds or are highly sporadic. Both of these options represent fungicide classes (FRAC 3 and 7) that are commonly applied during the growing season and are similarly vulnerable to development of resistance (FRAC 2019). Thus, in the overall system of peanut production, use of imidacloprid plus fluopyram or prothioconazole (plus fluopyram) may contribute to effective management of fungal diseases (e.g., leaf spot as well as certain soil diseases) but also have potential drawbacks related to cost, increased TSW, and, depending on in-season fungicide applications, exposure to similar fungicide modes of action potentially leading to more rapid selection for evolved resistance in leaf spot.

Phorate $(O, O$-diethyl- $S$-ethylthiomethylphosphorodithioate) is an organophosphate first registered for use on peanut as an insecticide in 1959 (U.S. EPA 2001). Since then, phorate has been understood to suppress development of TSW, caused by Tomato spotted wilt virus (Anco et al. 2020b; Culbreath and Srinivasan 2011; Haynes et al. 2019; Marasigan et al. 2016; Srinivasan et al. 2017), through the activation of plant defense responses including regulation of oxidative stress, signaling pathways, and proteins related to pathogenesis and defense (Jain et al. 2015). Accompanying these responses is a characteristic foliar phytotoxicity following emergence commonly referred to as "phorate burn" (Fig. 1), which can in cases result in noticeable leaf drop and be an obstacle to the adoption of phorate use. The main objective of this study was to examine the effect of phorate applied in-furrow at planting for management of late leaf spot on peanut. Alongside this was to determine the length during which phorate application could contribute significant suppression of late leaf spot development. Corresponding to these objectives was the hypothesis that phorate would suppress development of late leaf spot, because it has previously been demonstrated to suppress development of TSW, and that this effect would last for more than 50 days.

\section{Materials and Methods}

Experiments were conducted at the Edisto Research and Education Center (EREC) in Blackville, SC (2017 to 2019; Barnwell loamy sand; $33.364^{\circ} \mathrm{N},-81.329^{\circ} \mathrm{E}$ ), the North Florida Research and Education Center (NFREC) in Quincy, FL (2018 and 2019; 52\% Norfolk loamy fine sand and $48 \%$ Dothan-Fuquay complex; $30.546^{\circ} \mathrm{N}$, $\left.-84.588^{\circ} \mathrm{E}\right)$, and the Plant Science Research and Education Unit (PSREU) in Reddick, FL (2019; Gainesville loamy sand; $\left.29.403^{\circ} \mathrm{N},-82.180^{\circ} \mathrm{E}\right)$. Treatments consisted of a nontreated check or phorate and were generally replicated four times; five replications were conducted in EREC in 2019. Experimental design was a randomized complete block. Phorate (Thimet 20-G, 20\% phorate, AMVAC Chemical Corporation, Los Angeles, CA) was applied in-furrow at planting with a SmartBox calibrated to deliver $1.05 \mathrm{~kg}$ of active ingredient (a.i.)/ha at EREC from 2017 to 2019. Application rates at NFREC were 1.21 and $1.35 \mathrm{~kg}$ of a.i./ha in 2018 and 2019, respectively, with $1.64 \mathrm{~kg}$ of a.i./ha applied at PSREU in 2019. All seed were treated (Dynasty PD, 3.2\% azoxystrobin, 2\% fludioxonil, 0.4\% mefenoxam, Syngenta Crop Protection, Greensboro, NC), and all plots were inoculated at planting at the standard rate of 1 liter/ha (Optimize Liquid Peanut, $2 \times 10^{9} \mathrm{CFU} / \mathrm{ml}$ Bradyrhizobium spp., $1 \times$ $10^{-7} \%$ w/w lipo-chitooligosaccharide, Monsanto Company, St. Louis, MO). Seeding rate was approximately 19 seeds $/ \mathrm{m}$. Experiments at Blackville were planted 8, 30, and 20 May in 2017, 2018, and 2019, respectively. Plots in Quincy were planted 25 April 
2018 and 30 May 2019. The Reddick, FL, experiment was planted 14 May 2019. Blackville plots measured four rows on $96-\mathrm{cm}$ centers by $12 \mathrm{~m}$ in length. Reddick and Quincy plot rows were on $91-\mathrm{cm}$ centers and were $9.1 \mathrm{~m}$ in length. Conventional tillage was used in all experiments.

Planted cultivars in Blackville were 'Georgia-06G' (Branch 2007), 'Gregory' (Isleib et al. 1999), and 'FloRun 331' (Tillman 2019) in 2017, 2018, and 2019, respectively. Cultivars planted in Quincy included 'FloRun 157' (Sidhu et al. 2019), FloRun 331, Georgia-06G, Georgia-12Y, 'TUFRunner 297' (Tillman 2018), and 'TUFRunner 511' (Tillman and Gorbet 2017) in 2018 and Georgia-06G in 2019. Georgia-06G was planted in Reddick, FL, in 2019. Standard field management practices were performed throughout the growing season (Anco et al. 2019). The exception to this was the absence of fungicide applications during the growing season for all experiments in Blackville and Reddick, as well as in Quincy in 2019. In Quincy during 2018, eight fungicide applications were made following an approximately 15-day interval between 5 June and 13 September. Proportion of late leaf spot defoliation was visually estimated based on total canopy leaflets per plot. Defoliation ratings were made 23 and 31 August and 21 September 2017 (107, 115, and 136 days after planting [DAP], respectively; EREC), 18 September 2018 (147 DAP; NFREC), 7 August through 9 October 2018 on 14-day intervals (69 to 132 DAP; EREC), 7 August through 7 October 2019 on 14-day intervals (79 to 140 DAP; EREC), 7 July through 28 October 2019 on approximately 17day intervals (43 to 151 DAP; NFREC), and 12 June through 4 September 2019 on approximately 16-day intervals (29 to 113 DAP; PSREU).

To prevent loss of effect detection (i.e., comparing final defoliation ratings per location-year regardless of epidemic development in the absence of within-season fungicide coverage), defoliation ratings with the maximum treatment difference per experiment were selected for analysis. Sampling dates with maximum treatment differences per experiment were 21 September 2017 (EREC), $28 \mathrm{Au}$ gust 2018 (EREC), 18 September 2018 (NFREC), 20 August 2019 (PSREU), and 7 and 10 October 2019 (EREC and NFREC, respectively). Experiments were dug and inverted 26 September 2017 (EREC), 2 and 15 October 2018 (NFREC and EREC, respectively), 30 September 2019 (PSREU), and 9 and 28 October 2019 (EREC and NFREC, respectively). Plots were harvested 2 October 2017 (EREC), 2 and 22 October 2018 (NFREC and EREC, respectively), 4 November 2019 (NFREC), and 2 and 23 October 2019 (PSREU and EREC, respectively). Yields were adjusted to $10 \%$ moisture.

Data were modeled according to equation 1:

$$
y_{i j k}=\theta+\tau_{i}+u_{j k}+\varepsilon_{i j k}
$$

where $y_{i j k}$ is proportion late leaf spot defoliation from the $i^{\text {th }}$ treatment, $j^{\text {th }}$ replication, and $k^{\text {th }}$ experiment (location-year), $\theta$ is an intercept, $\tau_{i}$ is the fixed effect of treatment $i, u_{j k}$ is the random effect of the $j^{\text {th }}$ replication within the $k^{\text {th }}$ experiment, and $\varepsilon_{i j k}$ is the residual. Random effects relevant to the experimental design yet excluded from the analysis on the basis of not improving the model (Stroup 2013) included experiment and experiment $x$ treatment. Yield data were analyzed using a similar version of equation 1 that substituted treatment $i$ yield ( $\mathrm{kg} / \mathrm{ha}$ ) per replication $j$ and experiment $k$ for $y_{i j k}$, included the random effect of experiment $\left(+v_{k}\right)$, excluded the random $u_{j k}$ term following lack of model improvement, and modeled the response according to a gamma distribution with a corresponding log link. Analysis was performed using the GLIMMIX procedure of SAS 9.4 (SAS Institute, Cary, NC). Laplace approximation was used to improve standard error estimation (Pinheiro and Chao 2006; Stroup 2013). Estimated mean differences for defoliation data followed Fisher's protected least significant difference $(\alpha=0.05)$. Yield data were analyzed using a significance value of $\alpha=0.10$.

\section{Results}

Late leaf spot development. Late leaf spot was first observed in experiments 115, 69, 147 (leaf spot observations were not made prior to this date), 79, 64, and 50 DAP for EREC 2017, EREC 2018, NFREC 2018, EREC 2019, NFREC 2019, and PSREU 2019, respectively. Over the six location-years examined, in-furrow application of phorate corresponded to a highly significant $(P<0.0001)$ reduction in late leaf spot defoliation compared with nontreated peanut $(26 \%$ compared with 48\%) (Fig. 2). This corresponded to an epidemic progression during the point of maximum magnitude treatment difference per experiment for peanut treated with phorate being approximately $54 \%$ (slightly more than half) that of the nontreated control. Maximum defoliation differences between peanut treated with phorate and those nontreated per experiment ranged from 10.6 to $30 \%$ (Fig. 3) with a median value of $25.4 \%$. Although progression of late leaf spot infections varied in timing and severity across location-years, the response of peanut treated with phorate was overall consistent, including the NFREC 2018 experiment when eight fungicide applications were applied. Significant reductions in defoliation were observed as early as 64 DAP and as long as 147 DAP (Fig. 3).

Yield. Over the pooled data across experiments, pod yield was significantly greater for peanut treated with phorate $(2,330 \mathrm{~kg} / \mathrm{ha}) \mathrm{com}$ pared with nontreated peanut $(2,030 \mathrm{~kg} / \mathrm{ha})(P=0.0794$, Table 1$)$. Across individual location-years, data followed the same general pattern at EREC in 2017 and NFREC in 2018 (5,530 compared with 4,030 kg/ha for EREC and 4,470 compared with 3,360 kg/ha for NFREC, respectively, $P=0.0120$ and 0.0059). At PSREU in 2019, yields were comparatively much lower overall compared with other location-years; nevertheless, PSREU was the one experiment where yield was significantly greater for nontreated peanut compared with those treated with phorate (520 versus $340 \mathrm{~kg} / \mathrm{ha}$ ).

\section{Discussion}

This study documents for the first time that phorate applied infurrow at planting suppresses late leaf spot on peanut. Although the mechanistic elucidation of this phenotypic suppression was beyond the scope of this study, the phenotypic results reported here are in agreement with phorate's activation of plant defense response as reported for Tomato spotted wilt virus (Jain et al. 2015; Srinivasan et al. 2017). Supporting this is how significant suppression was

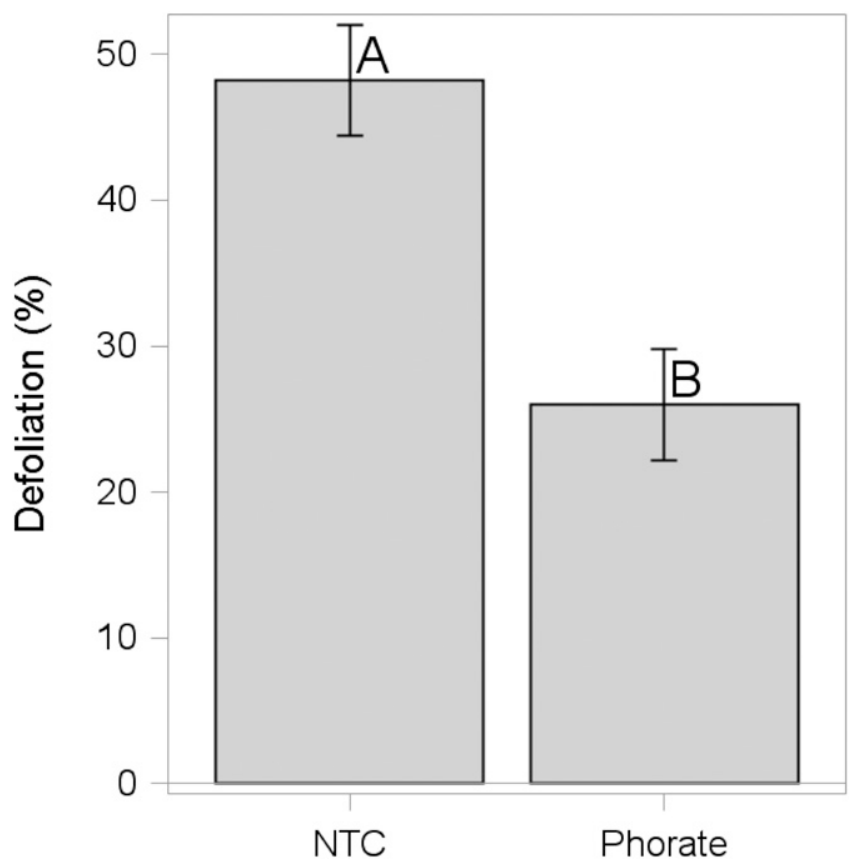

Fig. 2. Late leaf spot defoliation of peanut following in-furrow application of phorate at planting compared with the nontreated control (NTC) from six experiments conducted in Blackville, SC, Reddick, FL, and Quincy, FL, from 2017 to 2019. Bars with different letters are significantly different according to Fisher's protected least significant difference $(\alpha=0.05)$. Error bars are estimated standard errors. 
evident long after the seed furrow was closed (64 to 147 DAP) as well as how previous laboratory testing detected no difference (i.e., chemical residue) between peanut treated with phorate compared with nontreated controls 90 days after treatment (Diablo Laboratories 1964). Although phorate itself is a restricted use pesticide due to its toxicity (U.S. EPA 2001), it elicits a comparatively safe benefit of activating natural plant defense mechanisms (Jain et al. 2015).

Previously, imidacloprid-based insecticides (e.g., Admire Pro and generics) have been recommended to be paired with TSW-resistant
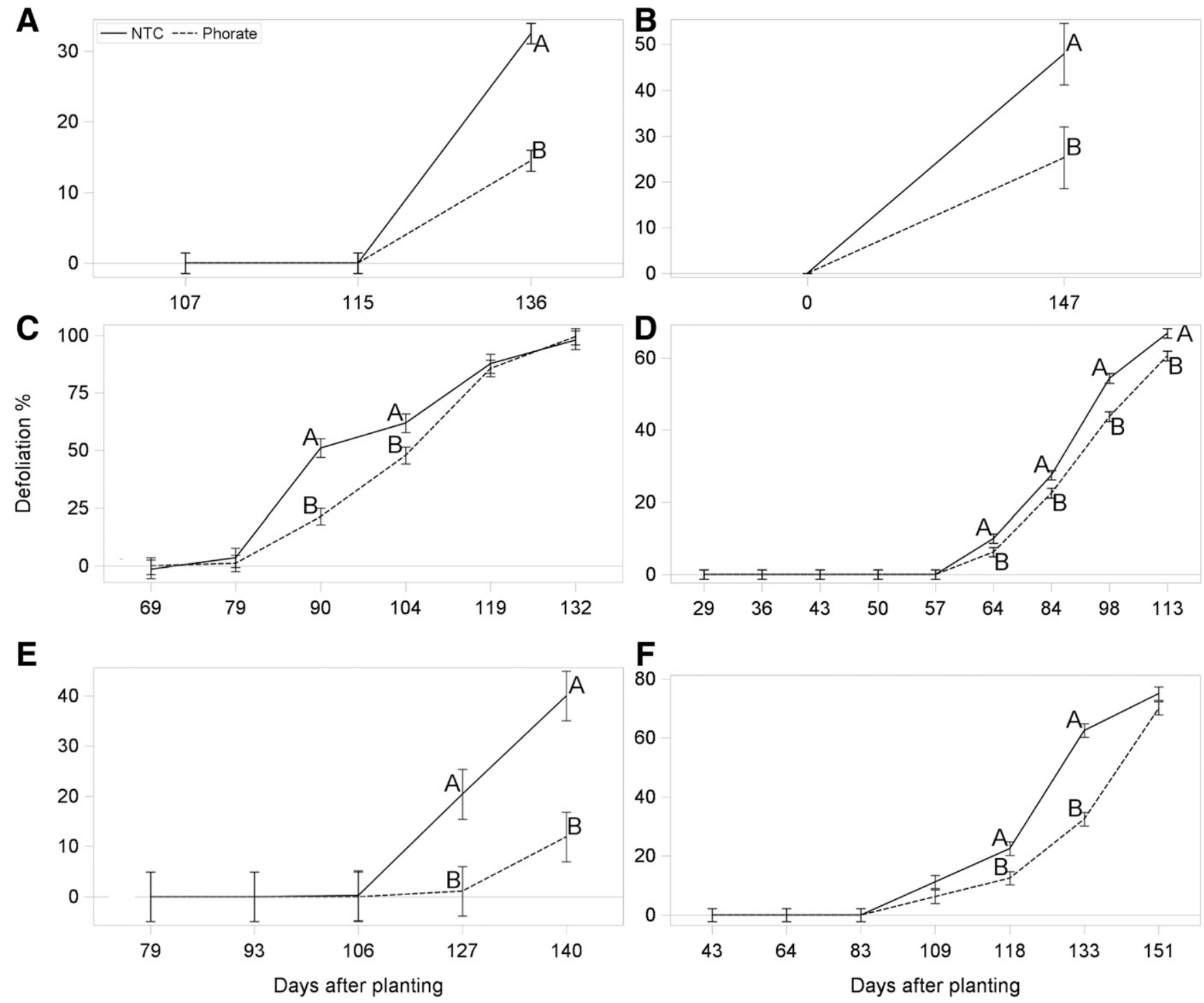

Fig. 3. Late leaf spot defoliation at increasing days after planting for peanut treated with phorate in-furrow at planting (dashed lines) compared with the nontreated control (NTC; solid lines). Experiments were conducted in Blackville, SC, in 2017 (A), 2018 (C), and 2019 (E), Quincy, FL, in 2018 (B) and 2019 (F), and Reddick, FL, in 2019 (D). Estimates from the same timing (days after planting) within the same location-year followed by different letters are significantly different according to Fisher's protected least significant difference at $\alpha=0.05$. Error bars represent the estimated standard error.

Table 1. Yield response ( $\mathrm{kg} / \mathrm{ha}$ ) of peanut treated with or without phorate at Blackville, SC, and Reddick and Quincy, FL, from experiments conducted from 2017 to $2019^{\text {w }}$

\begin{tabular}{|c|c|c|c|c|c|c|c|c|}
\hline \multirow[b]{3}{*}{ Treatment } & \multicolumn{6}{|c|}{ Location-year ${ }^{x}$} & \multirow[b]{3}{*}{ Combined } & \multirow[b]{3}{*}{$\mathrm{SE}^{\mathrm{y}}$} \\
\hline & \multicolumn{3}{|c|}{ EREC } & \multicolumn{2}{|c|}{ NFREC } & \multirow{2}{*}{$\begin{array}{c}\text { PSREU } \\
2019\end{array}$} & & \\
\hline & 2017 & 2018 & 2019 & 2018 & 2019 & & & \\
\hline $\mathrm{NTC}^{\mathrm{z}}$ & $4,032 \mathrm{~b}$ & 2,902 & 2,206 & $3,357 \mathrm{~b}$ & 2,212 & $517 \mathrm{a}$ & $2,030 \mathrm{~b}$ & 650 \\
\hline Phorate & $5,534 \mathrm{a}$ & 2,441 & 2,083 & $4,465 \mathrm{a}$ & 1,973 & $344 \mathrm{~b}$ & $2,334 \mathrm{a}$ & 749 \\
\hline$P>\mathrm{F}$ & 0.0120 & 0.2961 & 0.7157 & 0.0059 & 0.4620 & 0.0569 & 0.0794 & $\ldots$ \\
\hline
\end{tabular}

${ }^{w}$ Estimates followed by different letters are significantly different according to Fisher's protected least significant difference at $\alpha=0.10$. Data were analyzed on the gamma model scale, with estimates displayed on the inverse-linked data scale.

$x$ EREC $=$ Edisto Research and Education Center, Blackville, SC; PSREU = Plant Science Research and Education Unit, Reddick, FL; and NFREC = North Florida Research and Education Center, Quincy, FL.

y $\mathrm{SE}=$ estimated standard error of treatment yield for the combined data.

z NTC = nontreated control. 
peanut cultivars due to this resistance offsetting adverse effects of aggravated TSW severity levels and subsequent yield loss (Anco et al. $2019,2020 b$ ). Some of these cultivars have historically exhibited effective late leaf spot resistance. Within the past few years, Virginia market-type cultivars previously considered resistant to late leaf spot (e.g., Bailey and Sullivan) have exhibited late leaf spot infections and epidemic development characteristic of susceptible cultivars (Anco et al. 2019). In light of these changes in late leaf spot susceptibility of such cultivars, use of basic (liquid) in-furrow imidacloprid insecticides, although convenient and compatible with regard to cultivars with TSW resistance (Anco et al. 2020b), would not contribute protection against late leaf spot, which has become more severe in several peanut-producing areas including South Carolina. Along these lines, fungal diseases such as late leaf spot are characteristically more effectively managed through prevention than with reactionary measures postinfection. With the observation of infectious lesions on volunteer peanut plants as early as late May in some cases (Anco et al. 2020b), protective measures taken at planting (peanut in the United States are typically planted from mid-late April to early June), including application of phorate, can help mitigate early-season inoculum availability, with benefits extending through the remaining growing season.

Fungicide products currently labeled for in-furrow application for late and early leaf spot on peanut in the United States include prothioconazole (Proline), fluopyram plus prothioconazole (Propulse), and imidacloprid plus fluopyram (Velum Total) (Anco et al. 2019). Estimated product application costs of these fungicides are approximately $\$ 57, \$ 82$, and $\$ 84$ per hectare, respectively. Of these products, only imidacloprid plus fluopyram manages thrips, meaning application of prothioconazole or fluopyram plus prothioconazole infurrow, if applied for leaf spot protection, would need to include a separate insecticide to reduce injury from thrips and yield loss from TSW. Application of imidacloprid costs approximately $\$ 20 / \mathrm{ha}$, yielding a combined in-furrow application cost (not including inoculant as is consistent across pesticide choices) with prothioconazole or fluopyram plus prothioconazole of approximately $\$ 77$ or $\$ 102$ per hectare, respectively. Phorate, on the other hand, provides protection not only against thrips but also against TSW and, as documented by our results, leaf spot for a lower cost near \$37/ha. Depending on the comparison when considering the benefit to leaf spot management, application of phorate represents a product cost savings of $\$ 40$ to $\$ 65$ per hectare. The actual returns associated with use of phorate extend beyond product cost. When considering profitability in the relative absence of late leaf spot infections or plant parasitic nematodes, phorate has been reported to be $\$ 90$ and $\$ 160$ per hectare more profitable than imidacloprid or imidacloprid plus fluopyram, respectively, for cultivars moderately susceptible to TSW (relative to current commercial cultivars) (Anco et al. 2020b), but that this relationship changed across TSW-susceptibility groups. The overall yield response of phorate treatment across experiments included in the present study, where all but one experiment excluded fungicide applications during the growing season, provided a significant advantage of $300 \mathrm{~kg} / \mathrm{ha}$. This translates to an estimated potential economic benefit of $\$ 100$ to $\$ 110$ per hectare after accounting for the application cost of phorate for runner- and Virginia market-type cultivars, respectively. This yield savings assumes $4,480 \mathrm{~kg} / \mathrm{ha}$ yield potential and peanut contract prices of $\$ 470$ and $\$ 500$ per $1,000 \mathrm{~kg}$ for runner- and Virginia market-type cultivars, respectively. Although the overall yield response was significant (at $P=0.0794$ ) in this study, the protective effect against leaf spot defoliation was much more significant $(P<0.0001)$. If the consistent defoliation suppression results are applied to the meta-analytic relationship of defoliation and yield loss reported by Anco et al. (2020c), for which response variability existed among the $>100$ location-years examined, the potential defoliation reduction due to phorate application would on average correspond to a markedly similar net economic yield savings of $\$ 90$ to $\$ 120$ per hectare. Although this potential economic yield savings due to defoliation suppression potential may not always be realized under all possible (lower-severity) epidemics, the potential for defoliation-reduction associated yield savings remains a valuable profitability protection measure akin to an insurance benefit should greater amounts of leaf spot infections develop. Results of this study strongly support phorate application as an economical way to improve late leaf spot management in peanut crops where infection is a concern. In terms of the rate of epidemic progression, the decreased defoliation due to phorate application translates into a potential epidemic delay of approximately 7 days (Anco et al. 2020c), which can be particularly beneficial if adverse weather or field conditions prevent timely application of fungicides or harvest operations.

Suppression of late leaf spot epidemic development through plant defense activation by phorate represents an important boon for fungicide resistance management. Because phorate has efficacy against three targets on peanut (thrips, TSW, and leaf spot), its application makes for a considerably beneficial practice and one that provides a management buffer throughout the growing season in advance of infections. Disease suppression through induction of plant defense represents an additional mode of action compared with current commercial fungicides for leaf spot on peanut to facilitate greater rotation across modes of action and confers a broad spectrum contribution for which pathogen resistance is not known (FRAC 2019). At present and into the foreseeable future, there is a need for broad-spectrum (i.e., in terms of strain fungicide sensitivity) management tactics compatible with additional strategies due to the occurrence and cost of resistance (Deising et al. 2008; Hewitt 1998), intermittent product shortages, and international trade restrictions (e.g., propiconazole has been restricted by the EU) (World Trade Organization 2016).

Resistance management continues to be a pertinent issue across fungal pathosystems, late leaf spot on peanut included, because reduced fungicide efficacy and phenotypic resistance have been reported for several fungicide chemical classes (Culbreath et al. 2018, 2019; Munir et al. 2020; Stevenson and Culbreath 2006). Similarly, the nature of plant defense induction lends itself to compatibility with other IPM tactics, including crop rotation, conservation tillage, earlier planting dates, cultivar resistance (Kemerait et al. 2018), and strategic fungicide use including combined application of fungicides with micronized sulfur (Culbreath et al. 2019) and application of prothioconazole with fluxapyroxad plus pyraclostrobin (Anco et al. 2020a). Taken together, these factors support in-furrow application of phorate as an effective, economical, efficient (with regard to managing multiple pests), lasting, and robust management tool for peanut that can be integrated with a multitude of additional tactics. Although individual management decisions reflect multiple pertinent considerations, the collective advantages outlined herein to the use of phorate may outweigh stigma associated with its phytotoxicity or application.

\section{Literature Cited}

Anco, D., Thomas, J. S., Marshall, M., Kirk, K. R., and Smith, N. 2019. Peanu Money-Maker 2019 Production Guide. Circular 588. Clemson University Extension, Clemson, SC

Anco, D. J., Hiers, J. B., and Thomas, J. S. 2020a. Improved management efficacy of late leaf spot on peanut through combined application of prothioconazole with fluxapyroxad and pyraclostrobin. Agronomy (Basel) 10:298.

Anco, D. J., Thomas, J. S., and Monfort, W. S. 2020b. Efficacy and profitability of insecticide treatments for tomato spotted wilt management on peanut in South Carolina. Plant Dis. 104:1096-1104.

Anco, D. J., Thomas, J. S., Shew, B., Jordan, D., Monfort, W., Mehl, H., Small, I., Wright, D., Tillman, B., Dufault, N., Hagan, A., and Campbell, H. 2020c. Peanut yield loss in the presence of defoliation caused by late or early leaf spot. Plant Dis. 104:1390-1399.

Branch, W. D. 2007. Registration of 'Georgia-06G' peanut. J. Plant Regist. 1:120 Branch, W. D. 2013. Registration of 'Georgia-12Y' peanut. J. Plant Regist. 7: 151-153.

Chaisuekul, C., and Riley, D. G. 2001. Thrips (Thysanoptera: Thripidae) feeding response to concentration of imidacloprid in tomato leaf tissue. J. Entomol. Sci. 36:315-317.

Culbreath, A. K., Brenneman, T. B., Kemerait, R. C., and Stevenson, K. S. 2016. Changes in the efficacy of pyraclostrobin for control of peanut leaf spot diseases. (Abstr.) Proc. Am. Peanut Res. Educ. Soc. 48:67.

Culbreath, A. K., Brenneman, T. B., Kemerait, R. C., Jr., Stevenson, K. L., and Anco, D. J. 2019. Combinations of elemental sulfur with demethylation inhibitor fungicides for management of late leaf spot (Nothopassalora personata) of peanut. Crop Prot. 125:104911. 
Culbreath, A. K., Gevens, A., and Stevenson, K. 2018. Relative effects of demethylation-inhibiting fungicides on late leaf spot of peanut. Plant Health Prog. 19:23-26.

Culbreath, A. K., and Srinivasan, R. 2011. Epidemiology of spotted wilt disease of peanut caused by tomato spotted wilt virus in the southeastern U.S. Virus Res. 159:101-109.

Deising, H. B., Reimann, S., and Pascholati, S. F. 2008. Mechanisms and significance of fungicide resistance. Braz. J. Microbiol. 39:286-295.

Diablo Laboratories. 1964. Analysis of peanut meats, shells and foliage for possible residues of total Thimet. Report 4J7511, dated 26 February 1964.

Faske, T. R., and Hurd, K. 2015. Sensitivity of Meloidogyne incognita and Rotylenchulus reniformis to fluopyram. J. Nematol. 47:316-321.

FRAC. 2019. FRAC Code list 2019: Fungal control agents sorted by cross resistance pattern and mode of action (including FRAC code numbering). Fungicide Resistance Action Committee. https://www.frac.info/publications/ downloads

Gianessi, L. P., and Reigner, N. 2005. The value of fungicides in U.S. crop production. CropLife Foundation. https://croplifefoundation.files.wordpress.com/ 2012/07/completed-fungicide-report.pdf.

Haynes, J. M., Smith, N., Culbreath, A. K., Kirk, K. R., and Anco, D. J. 2019. Effects of insecticides applied in-furrow with superabsorbent polymer on peanut cultivars infected with tomato spotted wilt virus. Peanut Sci. 46: 127-139.

Hewitt, H. G. 1998. Page 221 in: Fungicides in Crop Protection. CAB International, Wallingford, U.K.

Holbrook, C. C., Ozias-Akins, P., Chu, Y., Culbreath, A. K., Kvien, C. K., and Brenneman, T. B. 2017. Registration of 'TifNV-High O/L' peanut. J. Plant Regist. 11:228-230.

Isleib, T. G., Milla-Lewis, S. R., Pattee, H. E., Copeland, S. C., Zuleta, C., Shew, B. B., Hollowell, J. E., Sanders, T. H., Dean, L. O., Hendrix, K. W., Balota, M., and Chapin, J. W. 2011. Registration of 'Bailey' peanut. J. Plant Regist. 5: 27-39.

Isleib, T. G., Pattee, H. E., Tubbs, R. S., Sanders, T. H., Dean, L. O., and Hendrix, K. W. 2015. Intensities of sensory attributes in high- and normal-oleic cultivars in the uniform peanut performance test. Peanut Sci. 42:83-91.

Isleib, T. G., Rice, P. W., Mozingo, R. W., Mozingo, R. W., II, and Pattee, H. E. 1999. Registration of 'Gregory' peanut. Crop Sci. 39:1526.

Jackson, C. S., Faske, T. R., and Kirkpatrick, T. L. 2014. Assessment of fluopyram for suppression of root-knot nematode (Meloidogyne incognita) in soybean. Pages 65-67 in: Arkansas Soybean Research Studies 2014. J. Ross, ed. University of Arkansas, Fayetteville, AR

Jain, M., Gallo, M., Chengalraya, K., Shaikh, N., MacDonald, G., and Davis, J. 2015. Phorate-induced host defence responses condition acquired resistance to tomato spotted wilt in cultivated peanut (Arachis hypogaea L.). J. Phytopathol. 163:853-866.

Kemerait, R., Culbreath, A., Prostko, E., Brenneman, T., Tubbs, S., Srinivasan, R., Abney, M., Monfort, S., Rabinowitz, A., Tillman, B., Dufault, N., Rowland, D.,
Mulvaney, M., Small, I., Hagan, A., Sarver, J., Anco, D., and Smith, N. 2018. Peanut Rx - Minimizing Diseases of Peanut in the Southeastern United States. The 2018 Version of the Peanut Disease Risk Index. University of Georgia Extension, Athens, GA.

Marasigan, K., Toews, M., Kemerait, R., Abney, M., Culbreath, A., and Srinivasan, R. 2016. Evaluation of alternatives to carbamate and organophosphate insecticides against thrips and tomato spotted wilt virus in peanut production. J. Econ. Entomol. 109:544-557.

Mehl, H. L. 2017. Evaluation of new high oleic Virginia-type peanut cultivars for disease tolerance, yield, and quality. Peanut Sci. 44:100-110.

Munir, M., Wang, H., Agudelo, P., and Anco, D. J. 2020. Rapid detection of fungicide resistance phenotypes among populations of Nothopassalora personata in South Carolina peanut fields. Plant Health Prog. 21:123-132.

Oka, Y., and Saroya, Y. 2019. Effect of fluensulfone and fluopyram on the mobility and infection of second-stage juveniles of Meloidogyne incognita and M. javanica. Pest Manag. Sci. 75:2095-2106.

Pinheiro, J., and Chao, E. 2006. Efficient Laplacian and adaptive Gaussian quadrature algorithms for multilevel generalized linear mixed models. J. Comput. Graph. Stat. 15:58-81.

Riley, D. G. 2007. Effect of imidacloprid on settling behavior of Frankliniella occidentalis and Frankliniella fusca (Thysanoptera: Thripidae) on tomato and peanut. J. Entomol. Sci. 42:74-83.

Sidhu, S. S., van Santen, E., George, S., Small, I., and Wright, D. L. 2019. Effects of planting date and irrigation on yield and grade in runner-type peanut cultivars in north Florida. Peanut Sci. 46:191-197.

Srinivasan, R., Abney, M., Culbreath, A., Kemerait, R., Tubbs, R., Monfort, W. and Pappu, H. R. 2017. Three decades of managing tomato spotted wilt virus in peanut in southeastern United States. Virus Res. 241:203-212.

Stevenson, K., and Culbreath, A. K. 2006. Page 52 in: Evidence of Reduced Sensitivity to Tebuconazole in the Peanut Leaf Spot Pathogens. American Peanut Research and Education Society, Savannah, GA.

Stroup, W. 2013. Generalized Linear Mixed Models: Modern Concepts, Methods and Applications. CRC Press, Boca Raton, FL.

Tillman, B. L. 2018. Registration of 'TUFRunner '297' peanut. J. Plant Regist $12: 31-34$

Tillman, B. L. 2019. FloRun '331' Peanut Variety. Publication SS-AGR-425. University of Florida, Gainesville, FL. https://edis.ifas.ufl.edu/ag425.

Tillman, B. L., and Gorbet, D. W. 2017. Registration of 'TUFRunner '511', peanut. J. Plant Regist. 11:235-239.

U.S. EPA. 1999. Reregistration eligibility decision chlorothalonil. EPA 738-R99-004. U.S. EPA Archive Document. https://archive.epa.gov/pesticides/ reregistration/web/pdf/0097red.pdf.

U.S. EPA. 2001. Phorate Interim Registration Document. U.S. Environmental Protection Agency, Washington, DC.

World Trade Organization. 2016. On-going review of maximum residue levels of pesticides in the European Union. Committee on Sanitary and Phytosanitary Measures. 16-3315. G/SPS/GEN/1494. 